AGH DRILLING, OIL, GAS • Vol. $31 \cdot$ No. $2 \cdot 2014$

http://dx.doi.org/10.7494/drill.2014.31.2.207

\author{
Stanisław Nagy*, Krzysztof Polański*, Jarosław Ślizowski*
}

\title{
THE POSSIBILITY OF APPLYING CAES TECHNOLOGY IN POLISH CONDITIONS
}

\section{INTRODUCTION}

The increasing popularity of energy from renewable sources brings about the necessity to develop technology that would enablecollecting and storingelectric energy.The analysis of possibilities of using energy fromrenewable sourcesin Polish conditions, indicates, that it is advisable for technology to put together both conventional gas turbine fuel and energy from renewable sources. That combinationwould allow a reduction of the energy produced by a turbine used for compression of air in the process of gaseous fuel combustion.

CAES (Compressed Air Energy Storage) installations, which use air compressed to the pressure of several dozen atmospheresthat is stored in underground storage facilities, are one of the examplesof the above-mentioned technology. During daily periods of high energy demand, air is drawn from storage facility and usedin combustion process in conventional turbine.So, the system bases on conventional gas turbine technology. However, recently, some new possibilities of applying compressed air turbines are being considered. This could eliminate the use of traditional gaseous fuel. Because of the necessity for underground storage facilities to be of a large capacity,a proper solution could be usingsalt cavern formations, abandoned mines orpore spaces of aquifers. At present, there are two CAES installations in the world: a power plant in Huntorf, Germany, settled in 1978 as emergency power supply of a nuclear power plant, and McIntosh in the United States, working since 1991. In both cases process air is stored in salt caverns. A situation in Polish conditionsis analogous,and from a practical point of view, we should consider only caverns developed in underground salt formations using solution mining method. In Poland, there are no abandoned mineswhich could be used for compressed air storage. Using aquifers for this purpose would not be any profitable because of expensive geological characterization and low well flow rates.

\footnotetext{
* AGH-UST, Faculty of Drilling, Oil and Gas, Krakow, Poland
} 


\section{THE EFFECTIVENESS OF CAES TECHNOLOGY BASED ON EXAMPLE OF THE HUNTORF'S POWERPLANT}

The solution proposed in CAES method causes significant energy savings, because:

- the whole amount of produced energy can be directed to a gas network,

- energy does not have to be directed to a gas network at the moment of production because of the possibility of storage.

A scheme of the power plant, including underground storage facilitiesand production parameters, is presented in Fig. 1.

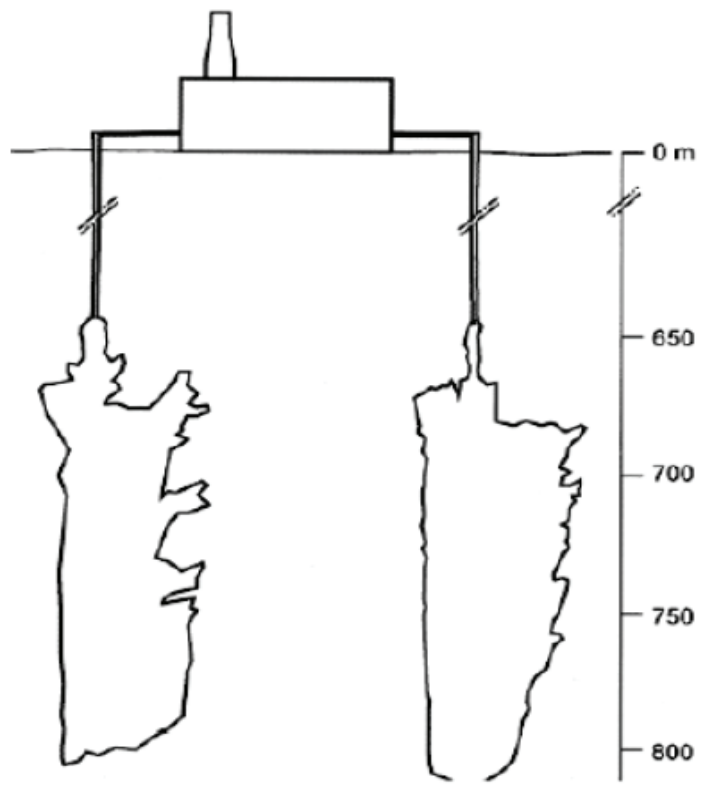

Fig. 1. Depths of underground storage caverns of the Huntorf's CAES power plant in Germany [2].

The parameters ofthe Huntorf's CAES installation:

- Volume of underground storage caverns: $310,000 \mathrm{~m}^{3}$

- (2 caverns of volumes of 140,000 $\mathrm{m}^{3}$ and 170,000 $\mathrm{m}^{3}$ )

- Total output of the power plant: $290 \mathrm{MW}$

- Time of discharging (emptying the caverns): 2-3 $\mathrm{h}$

- Input power: $60 \mathrm{MW}$ (the power of air compressors)

- Time of charging (filling the caverns): $8 \mathrm{~h}$

- Working pressure: 5 - $7 \mathrm{MPa}$

- Caverns' depth: 650 - $800 \mathrm{~m}$

- Total efficiency of the process: $42 \%$ 
A possible effectiveness of applying CAES technology in Polish conditions may be evaluated basing on parameters of the Huntorf's power plant presented in Fig. 1. During the analysis of the power plant's functioning, first of all, we should consider issues as follows:

- Storage caverns of a power plant are located at smalldepths, much shallower than optimal depth of natural gas storage caverns, which is $1200-1400$ MBGL.

- Comparing to natural gas storage cavities, CAES storage cavities work in relatively lowpressure ranges (5 - $7 \mathrm{MPa}$ for Huntorf). In accordance with Polish regulations [7], storage cavities located as in Huntorf should keep the pressure of stored gas fluctuating from the minimal pressure of compressor (which for Mogilno Cavern Underground Gas Storage is $3.3 \mathrm{MPa}$ ) up to $11.4 \mathrm{MPa}$.

- The project assumptions did not result from environmental factors but from technical and economicfactors, connected chiefly with strength of tubing (cannot be steel because of possible corrosion effect), casing and well cementation in conditions of considerable temperature variations that occur in power plants. Parameters of the power plant indicate, that well flow rate exceeds $1 \mathrm{MM} \mathrm{m}^{3} / \mathrm{h}$, which determinedusing 24 "- diameter tubing. The increase of depth would significantly influence the costs of casing as well as compressors' working costs. It would also increase flow resistance thus affectpower plant's efficiency.

Taking Huntorf's power plant parameters as a point of reference [1] (power of $290 \mathrm{MW}$, caverns' volume of $310,000 \mathrm{~m}^{3}$ and two-houremptying time), the operating volume of caverns $\mathrm{V}$ for generating power $\mathrm{P}$, should equal[8]:

$$
V=\frac{310}{2 \cdot 290} \cdot P \cdot t
$$

where:

$\mathrm{V}-$ operating volume, thousandsm ${ }^{3}$

$\mathrm{t}-$ working time, $\mathrm{h}$

$\mathrm{P}$ - power, MW

Thenumber of caverns that should be leached to reach required volume of Vdepends from two factors:

1) thickness of the reservoir that limits volume of the cavity to [7]:

$$
\mathrm{V}_{0}^{1}=2,8274(\mathrm{M}-85)
$$

2) limitation resulting from a possibility of emptying caverns in required time:

$$
\mathrm{V}_{0}^{2}=170 \mathrm{t} / 2
$$

The number of caverns $\mathrm{n}$ is defined by smaller of values:

$$
\mathrm{n}=\mathrm{V} / \operatorname{minimum}\left(\mathrm{V}_{0}{ }^{1}, \mathrm{~V}_{0}{ }^{2}\right)
$$

Usingabove relations, it is possible to estimate the number of caverns needed to get required power dependent on the reservoir thickness. Assuming thickness of about $200 \mathrm{~m}$, 
to reach the power approximating to Huntorf's power plant (300 MW) and emptying time of 2-3 hours, 2 caverns should be leached. If emptying time was increased to $8 \mathrm{~h}$, the number of necessary caverns would rise to 4 . Assuming power output at the level of $100 \mathrm{MW}$, and invariable thickness, 1 cavern would be enough, regardless of emptying time.

The required number of caverns could be diminished by increase of a tubing diameter or exploiting caverns with two wells.

\section{CHOOSING LOCATIONS FOR CAES INSTALLATIONS}

As mentioned before, salt caverns are the best formations to store compressed air in Polish conditions. Exploiting storage facility is accompanied by frequent pressure changes of stored air and, what is more important, amplitudes of the temperature are very high (rise of temperature because of air compression during injection and decrease during cavity emptying). This can affect properties of saltsurrounding cavern. Therefore, it is important to characterize all the processes happening in cavern during air storage. A proper characterization of these processes, relating to Polish conditions, may result in choosing the best locations for placing compressed air storage facilities and implementing CAES technology in the territory of our country.

While choosing possible locations, we should consider environmental factors as strength of wind, existence of salt formations of proper thickness and depth, as well as technical economic factors which are reservoir characterization, energy demand in theconsidered area and the possibility of leaching caverns(management of desalination brine).

The most significant aspect during initial selection of the location is the underground storage facility part, sochoosing a salt formation that would enable leaching caverns able to work under previously defined optimal conditions. The most important criteria of choosing location in terms of the surface part, is the access to the permanent source of renewable energy (wind blowing with the highest possible speed). However, due to the necessity of installing transmission lines between power plant(wind farm)and a turbine, the chosen location cannot be too distant from a selected location of the underground storage facility, because it would cause big energy losses in transmission network.

Although rock salt formations appear almost all over Poland, only a few can be considered as a location of a potential storage cavity. The regions are presented in Fig. 2. These are:

1. Salt bedded formation in the area of Zatoka Gdańska (Łeba Reservoir, Zatoka Pucka Reservoir and Mechelinki Reservoir) where cavities' roofs are at depths of 600 to $900 \mathrm{~m}$ (close to Huntorf's caverns' depth) and thicknessreaches $200 \mathrm{~m}$. At Mechelinki reservoir there is an underground storage facility which was leached using the possibility of dropping desalination brine to the Baltic Sea.

2. Salt dome formation Goleniów, near Zalew Szczeciśnki, where salt level depth is at about $900 \mathrm{~m}$. It is currentlycharacterizedwith geophysical methods and planned as a location for underground storage facilities of liquid hydrocarbons. 
3. Salt dome formations of the middle Poland area - Damasławek, Mogilno (with already existing gas storage facility), Kłodawa, Góra, Izbica, Lubień, Łanięta with salt level depth of 105 to 475 MBGL. We should keep in mind, that in case of salt dome formations, storage cavities should be placed preserving about 300 meters -thick layer of salt between the cavern roof and the next significant stratigraphic layer. Another inconvenience of cavities in salt domes is a big uncertainty regarding depth level of the cavern [9]. The advantage of such location is producing salt and the possibility of effective management of desalination brine.

4. Salt bedded formation near the Sudetian Monocline with the depth of over $1 \mathrm{~km}$ BGL. In this region, there was no solution mining before and according to regulations it is not possible to drop desalination brine to the surface streams.

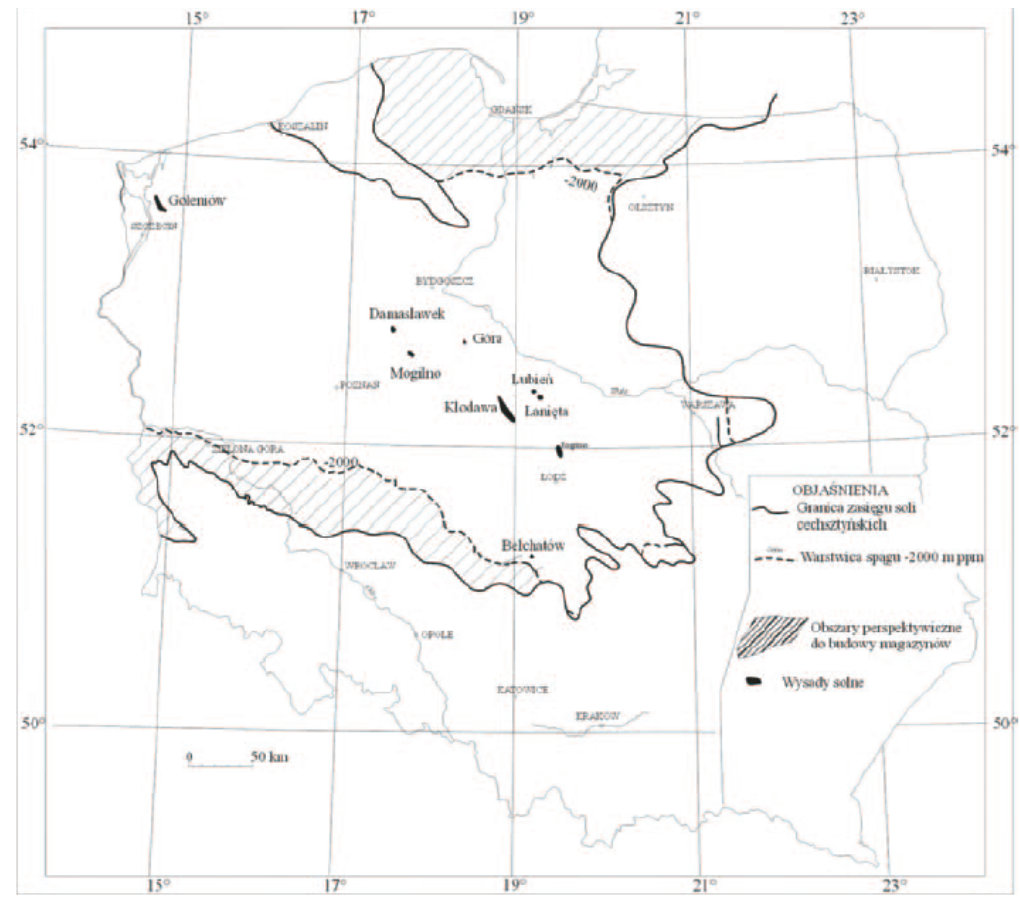

Fig. 2. Rock salt formations in the area of Poland [7].

The analysis ofmaps of mean annual wind speeds in Poland indicates that the perspective regions to build wind farms should include Baltic Sea shore area from Świnoujście to Gdańsk, and middle Poland region presented in Fig. 3.

Putting together the map of rock salt formations and the map of mean wind speeds, it can be observed, that the most favorable area for placing CAES power plant is the region of Wybrzeże Gdańskie/Zatoka Gdańska. This is the area of the highest mean wind speeds and there are also rock salt formations where the storage caverns can be leached near the shore. It would enable avoidingenergy transmission losses on a way from a wind farm (wind power plant)to the filling installation of underground storage facilities. 


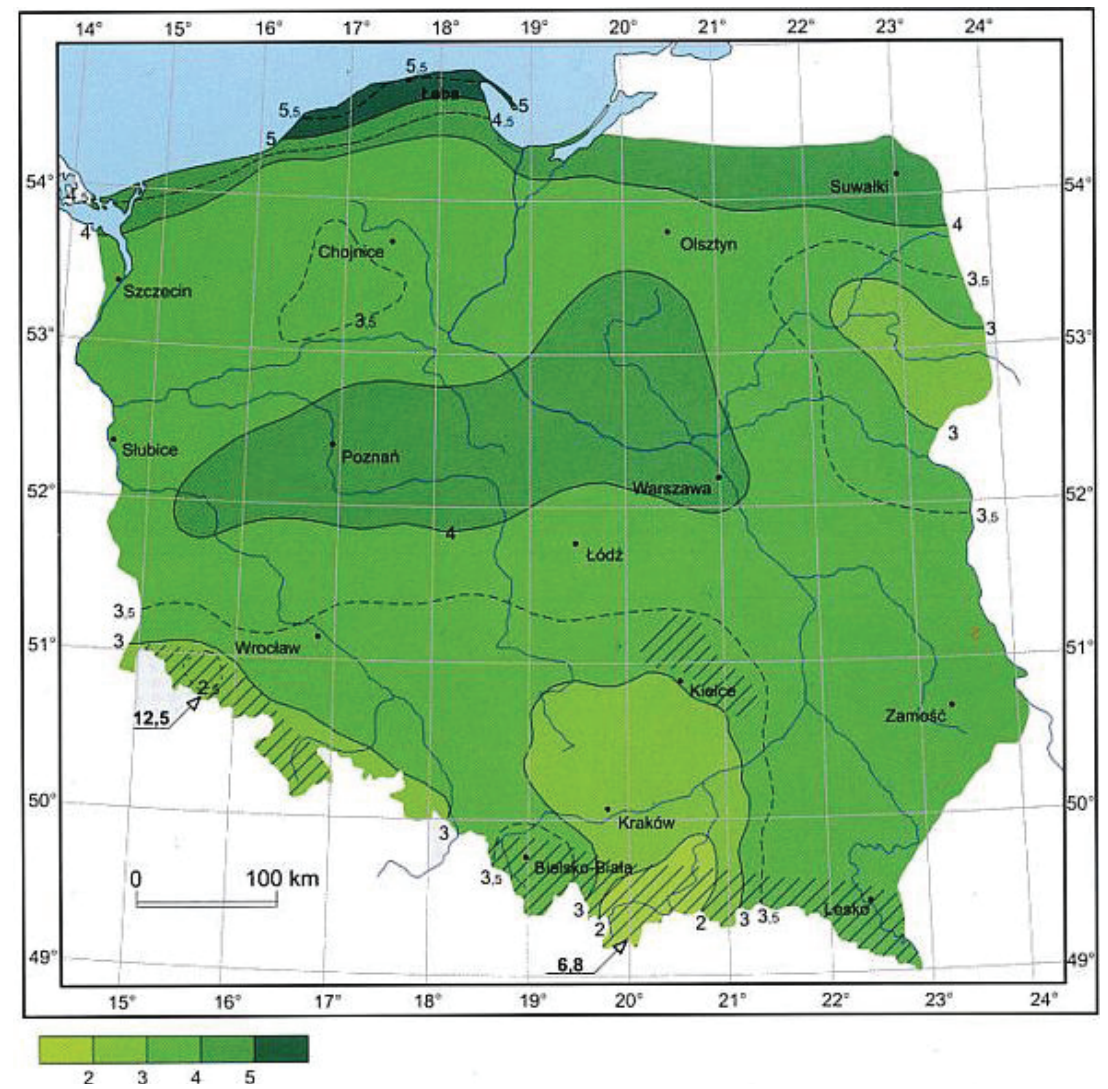

Fig. 3. Wind - mean speeds $10-\mathrm{min}$. $(\mathrm{m} / \mathrm{s})$

(altitude of $10 \mathrm{~m}$ in open area and asperity class of $0-1$ ) [11].

\section{SELECTED LOCATIONS}

The cheapest and the fastest way to build a storage facility is choosing location near already existing oil and gas storage facilities i.e. Mogilno CUGS and Kosakowo CUGS. Places which are also considered are storage facilities in salt dome formations Damasławek, Lubień and Łanięta. It is hard to indicate best of the options, because although it is possible to build bigger cavities in salt domes, such investment has high uncertainty level. In case of Kosakowo, a probability of a negative well is much lower, but only smaller cavities can be built.Basing on the analyses of rock salt formations and mean wind speeds, the most favorable locations for CAES installations in Poland are in the region of Wyniesienie Leby and Zatoka Pucka. The potential places for CAES installations in these areas are presented in Fig. 4 and Fig. 5, including also twelve indications considering surface factors. 


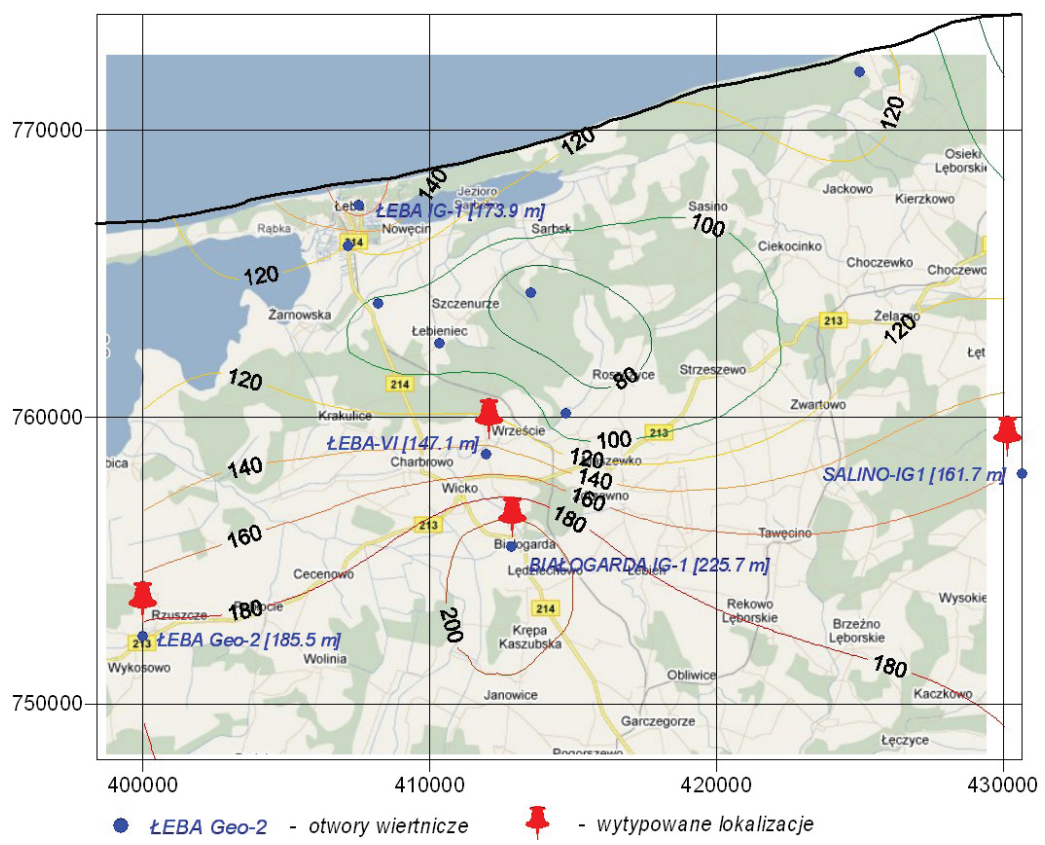

Fig. 4. Map of potential salt caverns locations for storage of compressed airin the area of Łeba reservoir [8].

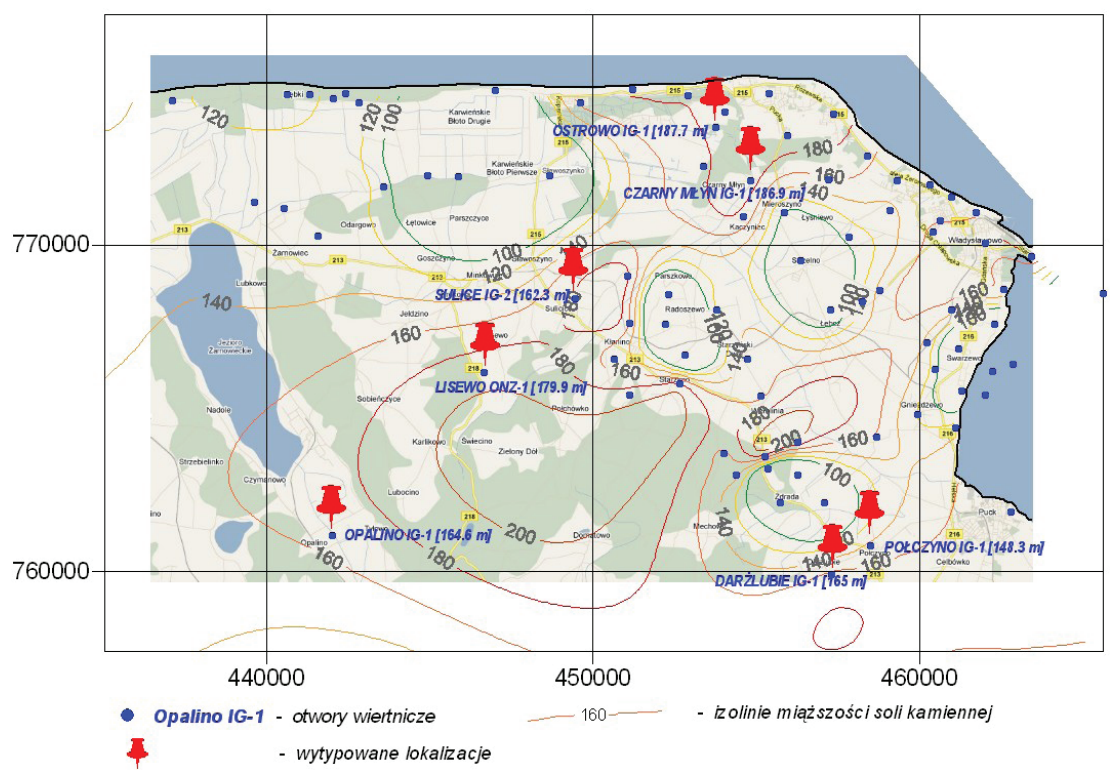

Fig. 5. Map of potential salt caverns locations for storage of compressed air in the area of Zatoka Pucka reservoir [8]. 


\section{SUMMARY}

Storage facilities using the energy of compressed air let the production of the electric energy become independent, to a large extent, of a permanent access to the source of renewable energy (wind).If the power of blowing wind does not reach a minimal required level needed for propelling a wind turbine round the clock, in the periods of "wind stillness" the energy accumulated in compressed air can still be used for maintaining production. Owing to this, implementation of CAES technology should be chiefly considered in regions where such "still" periods occur. This could be a supplement to the wind power industry, when producing from wind turbines is not possible.However, the main purpose of CAES technology application is meeting the needs of a peak demand. This is why all the locations considered in the article were the areas of the highest mean wind speeds, which makes those regions the most attractive in terms of building wind farms for compressors' propulsion.

The analysis shows that implementation of CAES technology is more difficult than building an underground natural gas storage facility, which is connected with huge efficiencies of gas - receiving installations. Research in this topic should focus on characterizing thermodynamic processes which occurin storage cavities and proper selection of well completion.

\section{REFERENCES}

[1] Crotogino F.:Compressed Air Storage.First International Renowable Energy Storage (IRES I) Conference, Gelsenkirchen. Oktober 2006.

[2] Dzierżanowski Ł.: CAES Power plants.Electric Energy Magazine - No. 2-3/2011.

[3] Kunstman A., Poborska-Młynarska K., Urbańczyk K.: Geological and mining aspects of salt storage caverns WYKONANIE. Geological Overview - No. 9/2009 Vol. 57.

[4] Radziewicz W.: System magazynowania energii CAES a energetyka wiatrowa. Wojciech, („Energetyka” - nr 2-3/2011).

[5] Robb D.: The CAES for wind. Renewable Energy Focus, Volume 12, Issue 1, January-February 2011, Pages 18-19.

[6] Samotyj M.: Złapać wiatr i pod ziemię! Materiały problemowe Cire 2012.

[7] Ślizowski J., Urbańczyk K.: Możliwości magazynowania gazu ziemnego w polskich złożach soli kamiennej w zależności od warunków geologiczno-górniczych. Kraków 2011

[8] Ślizowski J., Urbańczyk K., Lankof L., Serbin K.: Wytypowanie możliwych lokalizacji podziemnych zbiorników do magazynowania energii w postaci sprężonego powietrza z punktu widzenia wykorzystania podziemnych struktur geologicznych we wskazanych obszarach Polski. Opracowanie niepublikowane IGSMiE PAN 2011.

[9] Urbańczyk K., Ślizowski J.: An attempt to asses suitability of middle-Poland salt domes for natural gas storage., Archives of Mining Sciences, vol. 57, issue 22012.

[10] Wang S.Y., Wu J.L.:Optimal sizing of the CAES system in a power system with high wind power penetration. International Journal of Electrical Power \& Energy Systems Volume 37, Issue 1, May 2012, Pages 117-125

[11] http://www.f3f-klif.pl/2010/10/zasoby-wiatru-w Polsce [14.03.2014r.] 